\title{
EXTERNAL MORPHOLOGY OF PINUS TIMLERI SEED CONES FROM THE NEOGENE OF THE LOWER RHENISH BASIN, W GERMANY
}

\author{
ROLF GOSSMANN ${ }^{1, *}$, PHILIPP L. KNAUS ${ }^{2}$ \\ ${ }^{1}$ Ossietzkystraße 5, D-53123 Bonn, Germany; e-mail: rolf.gossmann@web.de. \\ 2 Steinmann Institute, University of Bonn, Nussallee 8, D-53115 Bonn, Germany. \\ * correponding author
}

Gossmann, R., Knaus, Ph. (2018): External morphology of Pinus timleri seed cones from the Neogene of the Lower Rhenish Basin, W Germany. - Fossil Imprint, 74(1-2): 189-195, Praha. ISSN 2533-4050 (print), ISSN 2533-4069 (on-line).

\begin{abstract}
The external morphology of Pinus timleri seed cones is described from exceptionally well preserved cones and cone fragments from the Lower Rhenish Basin (Germany). The seed cones are asymmetric with a smooth side and erect umbos on the apophyses of the other side. We hypothesise that the smooth side presents the shadow-exposed side while the side with more erect umbos is the light-exposed side as in many extant Pinus seed cones.
\end{abstract}

Key words: morphology, seed cones, Pinus, Lower Rhenish Basin, Germany, Neogene

Received: December 31, 2017 | Accepted: April 15, 2018 | Issued: August 31, 2018

\section{Introduction}

The type material of Pinus timleri KinKelin in EngelHardT et KinKELIN, 1908 stems from the Frankfurt "Klärbecken" flora of Pliocene age, which was lost during World War II (for details see Kvaček et al. 2014a: 25, Kvaček et al. 2014b: 135). Later, new material of P. timleri was found in the Lower Rhenish Basin (Kilpper 1968, Wutzler 1989, Gregor 1994, Kvaček et al. 2014a, b), i.e. from the Zanclean (Hauptkies member) of the Frechen Mine and from deposits of the upper Zanclean and Piacenzian of the Hambach Mine. All material comes from open cast mines. The mostly incomplete seed cones are often opened in situ through desiccation, or are strongly abraded. Due to usually poor preservation, taphonomic artifacts have previously been described as diagnostic characters (Kilpper 1968). Detached complete seed cones which were not abraded and retain moisture (thus remaining closed and simpler to study) are rare. Here we describe the complete external morphology from exceptionally well preserved seed cones.

\section{Material and stratigraphic range}

Well preserved unabraded seed cones and cone fragments were studied from several collections and were compared with the suggested neotype specimen from the "Hauptkiesserie" of the Frechen Mine (Ruhr Museum Essen - RE 551.782.210 A 0066/1, leg. Kilpper, pl. 2, fig. 3; see Kilpper 1968, Kvaček 1976, Mai 1986, Kvaček et al. 2014a, b). All new material (Wutzler 1989) was recovered from the Pliocene of the Hambach Mine (details below). A detailed comparison with the characteristics of seed cones which until now were placed in Pinus timleri shows that the Hambach material belongs to the same taxon (Engelhardt and Kinkelin 1908, Seward 1919, Mädler 1939, Florin 1963, Kilpper 1968, Kvaček 1976, Mai 1986, Farjon 2005).

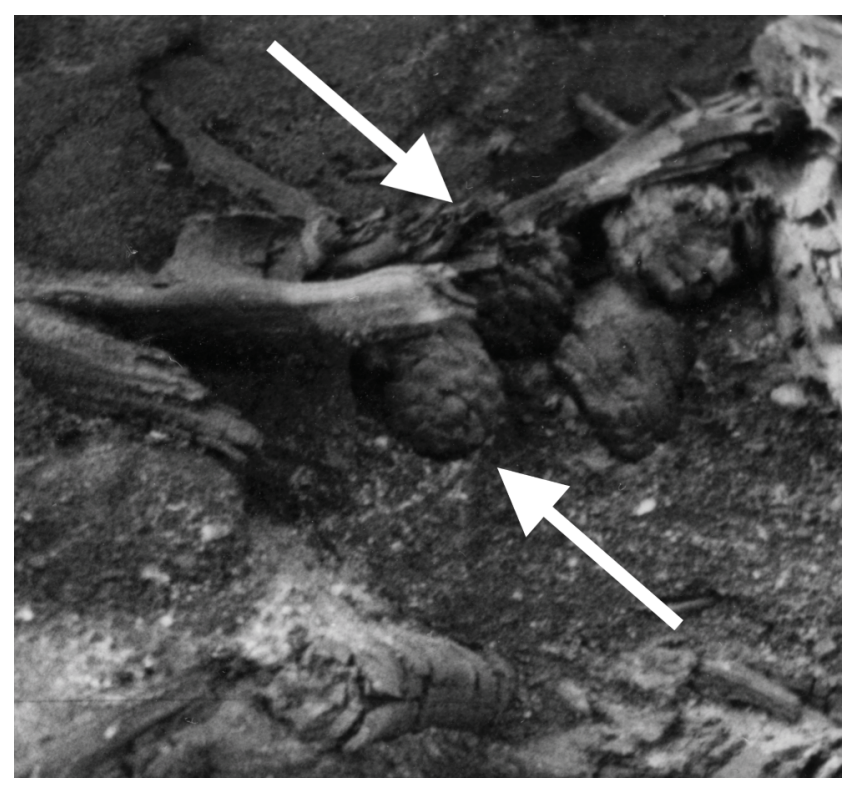

Text-fig. 1. Photograph of supposed Pinus timleri cones in a sandy drift bed from the abandoned Düren open cast mine (Photo: R. Köditz), see arrows. 
Unpublished lecture notes of the late R. Köditz (Eschweiler, Germany) from January 1971 contain a monochrome photo which shows a section of the drift layers of Upper Miocene age overlying sands in the Düren Mine in 1960. The photo clearly shows large conifer cones with strongly thickened apophyses resembling those of $P$. timleri.

The material could not be safely recovered from the steep embankment at the partially flooded Düren mine and is thus unavailable for study. Judging from the photograph, the specimens most likely belong to $P$. timleri and might thus extend the range of the taxon to Düren Mine (Upper Miocene, Inden Formation, horizon 7) from the stratigraphically younger localities of Frechen Mine (lowest Pliocene, Kieseloolith Formation, Erft member = upper Hauptkies member, horizon 8B), and Hambach Mine (upper Zanclean, Kieseloolith Formation, Bergheim member = Rotton member, horizon sands 9B, and Piacenzian, Kieseloolith Formation, Reuver member, horizon sands 10 ), with $P$. timleri thus ranging from the Upper Miocene to the later Pliocene (Schneider and Thiele 1965, Hager 1977, Deutsche Stratigraphische Kommission 2016; Geologischer Dienst NRW 2016 - Stratigraphische Tabelle des Tertiärs, available on-line https://www.gd.nrw.de/zip/ ge_ev tabelle tertiaer.pdf). All material described in this paper was collected from horizon 9B, with the exception of the Frechen cone. Seed cones in different stages of abrasion are a common occurrence in the sandy beds overlying the Rhenish browncoal seams (e.g. Gossmann 1983, Gossmann et al. 2006). Why seed cones of Pinus timleri were only rarely found in two mines (and possibly in a third) is unknown. Smaller seed cones of the species are also known from the Pliocene of Hostens S of Bordeaux (France). This material is partly housed in the Huard collection at the University of Montpellier (Kvaček et al. 2014b).

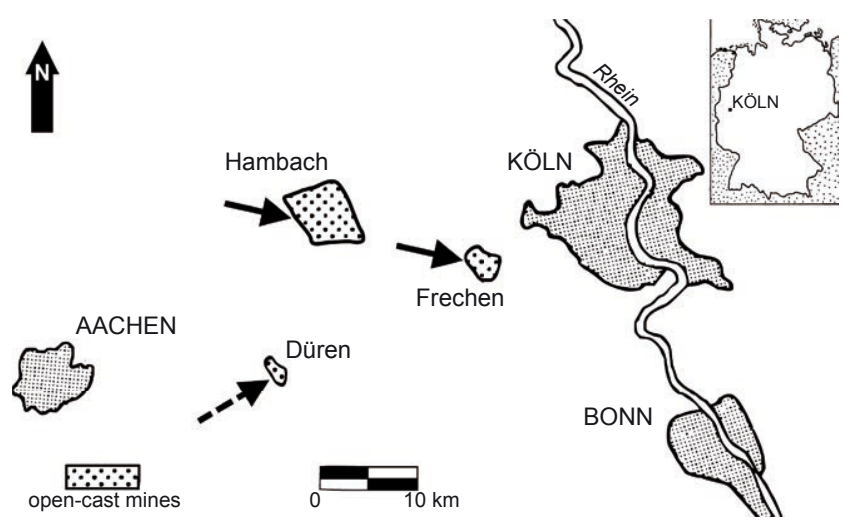

Text-fig. 2. Map of browncoal mines with Pinus timleri occurrence: dashed arrow indicates estimated occurrence (source: Pingen 2001).

The seed cones published in this paper from the collections of M. Pingen, W. Spaeth and R. Gossmann (later housed in the Steinmann Institute, University of Bonn: STIPB PB 21243) were conserved using polyethyleneglycol 4000. The cone from the Augsburg Natural History Museum (Reg.-Nr. 2016-67/1979, leg. Gregor) was additionally treated with petroleum based wax. The polyethyleneglycol conservation technique has been proven to prevent damage to specimens through handling and to facilitate the determination of cones by preventing their opening.

\section{Geological setting}

Tectonic tension between the Bergisches Land in the $\mathrm{NE}$ and the Eifel Mountains in the SW resulted from the formation of the Alps during the late Paleogene. These forces led to subsidence of the Rhenish Massif between the two structures at a width of 50 to $60 \mathrm{~km}$. During the Early Oligocene, a graben formed to the NW of the Rhenish Massif and filled with sand and gravel originating mostly from the $\mathrm{S}$. The sediment cover is divided into several fault blocks through surface faults. During the Miocene and Pliocene the sea level retreated from this region to the NW giving way to large continuous swamp forests and fens. Here, an extensive coal seam and further smaller coal seams formed, which have been mined for centuries from outcrops and small pits, later as open cast mines. The main coal seam subsided up to $400 \mathrm{~m}$ and was covered by clay, sand, gravel, and the Pleistocene loess layer. Currently, only Garzweiler, Inden, and Hambach Mines are still in operation.

\section{Context}

The described and figured seed cones were transported from their place of growth to sandy deposits, drift horizons with wood, bark, cones, and, occasionally, fruits or seeds. The mother trees must have grown close to the deposit since the cones show little to no transport damage. Pinus timleri seed cones with significant transport damage are much more common than undamaged specimens from Hambach open cast mine. P. timleri presumably grew mostly in the vicinity on sand bars with acidic soil or on nutrient poor deposits of nearby rivers (Van der Burgh 1983, Mai 1995). Only here the conifers could out-compete "dicot" angiosperms.

\section{Systematic palaeobotany}

(Current systematics based on Chase and Reveal 2009 together with Christenhuz et al. 2011.)

\section{Order Pinales Gorozhankin, 1904 \\ Family Pinaceae Sprengel ex F.Rudolphi, 1830 (nom. cons.)}

Genus Pinus L., 1753

Pinus timleri Kinkelin in Engelhardt et Kinkelin, 1908 Pl. 1, Figs 1, 2, Pl. 2, Figs 1-3

Selected synonyms:

1887 Pinus cembra L. fossilis GeYler et KinKelin, p. 14, pl. I, fig. 8.

1900 Pinus aff. laricio PoIr. fossilis Kinkelin, p. 127.

*1908 Pinus timleri Kinkelin in Engelhardt et KinKelin, p. 205, pl. 25.

Pinus aff. laricio PoIr. pliocaenica KInKelin; Kinkelin in Engelhardt and Kinkelin, pro parte, p. 210, pl. 24, fig. 12.

1919 Pinus timleri KinKelin; Seward, p. 394, text-fig. 786A, 786B. 
1939 Pinus timleri Kinkelin; Mädler, p. 33.

1968 Pinus timleri Kinkelin in EngelH. et KinKelin; Kilpper, p. 161, pl. 44, figs 9-13.

1986 Pinus timleri KinKelin; Mai, p. 574, 578, pl. 45, fig. 1.

1989 Pinus timleri; Wutzler, p. 10, pl. 8, fig. 2a, 2b.

1994 Pinus timleri; Gregor, pl. 13, fig. 3.

1994 Pinus urani (Unger) Schimper; Mai, p. 215 pro parte, pl. IV, figs 1-3.

2014a Pinus timleri KinKelin in Engelhardt et Kinkelin; Kvaček et al., p. 21, pl. 1, pl. 2, figs 1-3, pl. 3, pl. 4, figs 1-2.

2014b Pinus timleri KinKelin; Kvaček et al., p. 137, pl. 1, figs 3-10, pl. 2, pl. 3, figs 1-5.

N o t e . Kvaček et al. (2014a) and Kvaček et al. (2014b) gave a description of the overall taxon. The present work is focused on the specific external morphology of the seed cones.

Description of seed cones. Based on well preserved female cones and cone fragments of $P$. timleri without transport damage, the articulated appearance of the cones is asymmetric and features a highly variable morphology of the apophyses. The whole $P$. timleri seed cones have a total length of 15.2 to $17.2 \mathrm{~cm}$ and a maximum width of 7.2 to 9.5 cm (see Pl. 1, Figs 1a, b, 2b-d, Pl. 2, Fig. 1a, b) (other seed cones show a length up to nearly $28 \mathrm{~cm}$ ). The cone axis is bent concavely towards the smooth side (Pl. 1, Fig. 1a), while the opposite side shows a convex shape. Incomplete seed cones tend to disarticulate towards the base so that some cone scales must be picked up from the sediment while the moist cone apex resists disarticulation until desiccation (P1. 2, Figs 2a, b, $3)$. Only rarely are cones preserved with the short peduncle (Pl. 1, Fig. 2f), most specimens are broken off at the base (Pl. 1, Fig. 1d). The apex has a rounded shape and compact structure (Pl. 1, Fig. 2e, Pl. 2, Fig. 2c).

Most cones show broad-rhombic shaped apophyses with a mucro on the smooth side, sometimes with slight horizontal ridges (Pl. 1, Fig. 1a, 2c, Pl. 2, Fig. 2a). The small umbo of the smooth side is not concave (denticulato-mucronate; $\mathrm{Pl}$. 1, Fig. 2c). On the opposite side, the (excentrodenticulate to mucronate) umbo is strongly conical and sometimes hookshaped (Pl.1, Fig. 2d) or nearly hemispherical (Pl. 1, Fig. 2f) and can feature radial grooves (Pl. 1, Fig. 1f). The raised umbo may also bear a roundish erect navel (Pl. 2, Fig. 1c), which can feature a recurved mucro (prickle) (Pl. 2, Fig. 1b). Occasionally, the mucros are eroded on the side with the thinner umbos. In this case, the apophyses appear slightly concave. This feature is therefore of taphonomic origin and not a morphological character. It can be observed in the scales of the Frechen cone (Pl. 2, Fig. 3).

Extinct and extant seed cones. Seed cones of $P$. timleri apparently most often broke off the tree in an incomplete state since their bases remained with scales on the branch or even initially on the trunk. Only later did the base separate or decompose in place on the dead tree. Extant large heavy seed cones, e.g. Pinus canariensis SweET ex K. Sprengel, $P$. pinea L. or P. radiata D.Don (see Page 1974, cf. Klaus 1980, Krüssmann 1983, Klaus 1989, Schütt et al. 2004, Farjon 2005) show the same pattern.

In addition to the usual variation, the morphology of a seed scale depends on the position of the scale on the

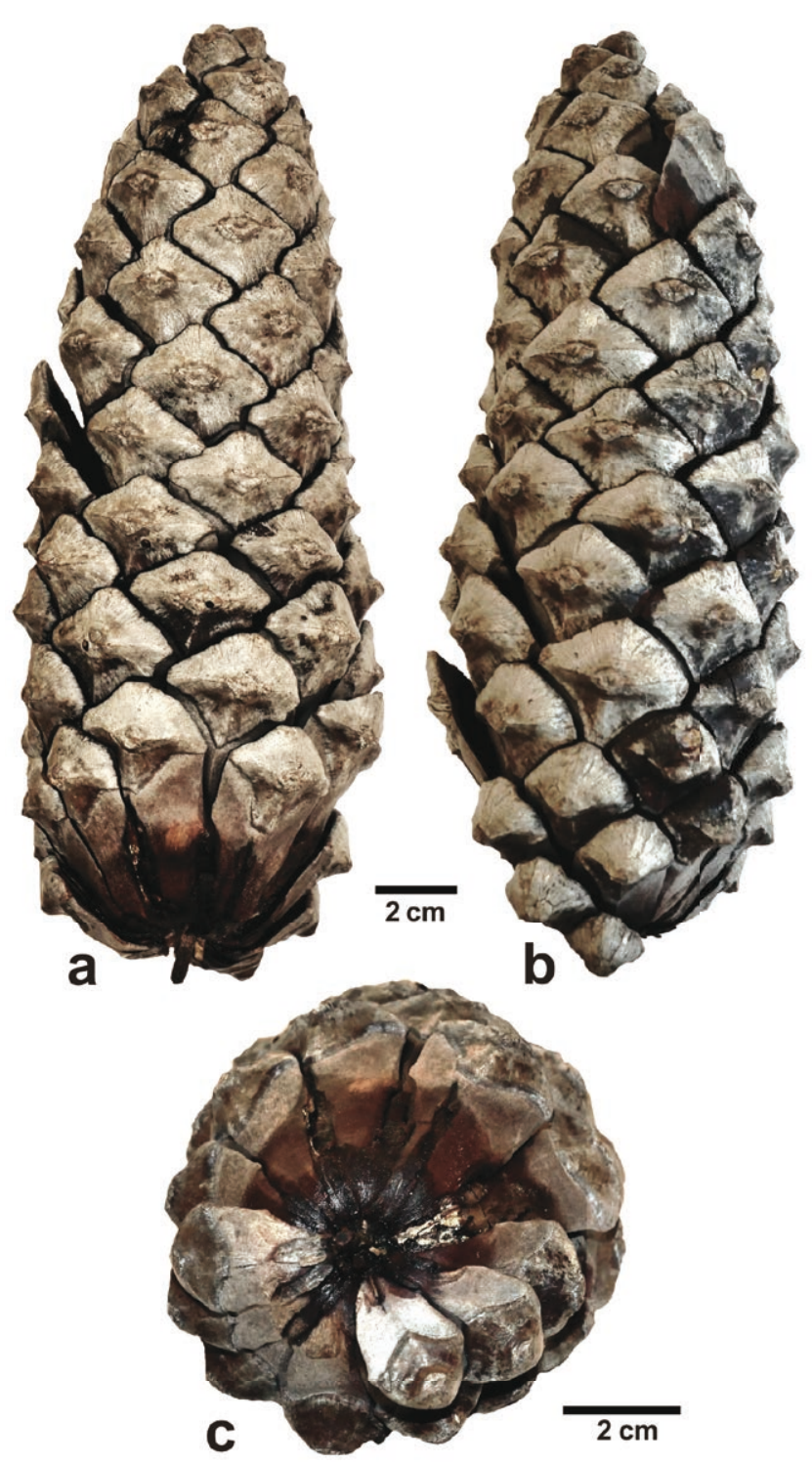

Text-fig. 3. Extant seed cone of Pinus canariensis SweEt ex K.SPRENGEL from south-facing slope of the Teide-Plateau of Teneriffa, Canary Islands, Spain. a) Shadow-exposed side of cone. b) Light-exposed side of cone. c) Cone base at break surface (cone is housed in the Goldfuß Museum in Bonn under reg.-nr. STIPB PB 23562r).

cone. In many extant Pinus species, the shadow-exposed sides of the cone feature flat apophyses. On the opposite side that is exposed to direct light the apophyses of cone scales are thickened, presumably as protection against seed predation. This is particularly true of $P$. canariensis SwEET ex K.Sprengel (Text-fig. 3a-c) and P. roxburghii SARG, the species morphologically most similar to P. timleri (see Page 1974, Klaus 1980, Krüssmann 1983, Schütt et al. 2004, Kvaček et al. 2014a, b). We hypothesise that the same relationship of direct light exposure and asymmetric growth was present in P. timleri and similar fossil seed cone taxa.

\section{Conclusion}

The description of the seed cones demonstrates their asymmetric nature. One side of the cones presents a 
smooth surface while the other bears erect apophyses. We hypothesise these different sides to present shadow- and light-exposed sides respectively as in many recent conifer seed cones. We stress the importance of distinguishing organic and taphonomic features of fossil conifer cones.

\section{Acknowledgements}

We are grateful to the editor for giving us the chance to honour Zlatko Kvaček on the occasion of his $80^{\text {th }}$ birthday. We thank RWE Power AG, Essen, for the annual opportunity to collect and dig with the Paläobotanisch-Biostratigraphische Arbeitsgruppe (PBA), under the guidance of Dr. H.-J. Gregor, in Hambach open cast mine and other Rhenish mines. Special thanks also go to the former company geologist Dr. B. Wutzler (Bornheim) and to Ing. U. Lieven (Bedburg) for their support of this digging and survey work. Further, we thank the collectors and institutions for loaning the provided Pinus seed cones: Mrs. M. Pingen (Hürtgenwald-Gey), Mr. W. Spaeth (Euskirchen-Büllesheim) and Dr. H.-J. Gregor (Olching, Bayern/Naturmuseum Augsburg). Mr. U. Lieven (Bedburg) we further thank for a copy of the unpublished notes of R. Köditz with some old photographs and for stratigraphic advice. We are thankful to Dr. H. Winterscheid (Bonn) for taxonomic advice. We are indebted to $\mathrm{Mr} \mathrm{G}$. Oleschinski (Steinmann Institute, Palaeontology, of the University of Bonn) and Mr. J. Goell (Alfter Gielsdorf), for photographs and individual image editing and/or technical help with the production of text figures and plates. And finally we are also grateful to the two reviewers, Drs. L. Kunzmann and V. Teodoridis, for their helpful advice.

\section{References}

Chase, M. W., Reveal, J. L. (2009): A phylogenetic classification of the land plants to accompany APG III. - Botanical Journal of the Linnean Society, 161: 122-127. https://doi.org/10.1111/j.1095-8339.2009.01002.x

Christenhuz, M. J. M., Reveal, J., Farjon, A., Gardner, M. F., Mill, R. R., Chase, M. W. (2011): A new classification and linear sequence of extant gymnosperms. - Phytotaxa 19: $55-70$. https://doi.org/10.11646/phytotaxa.19.1.3

Deutsche Stratigraphische Kommission (Menning, M., Hendrich, A. (eds)) (2016): Stratigraphische Tabelle von Deutschland 2016 ( $2^{\text {nd }}$ ed.). - GeoForschungsZentrum, Potsdam, 1 p. (available on-line)

Engelhardt, H., Kinkelin, F. (1908): Oberpliozäne Flora und Fauna des Untermaintales, insbesondere des Frankfurter Klärbeckens. - Abhandlungen der Senckenbergischen Naturforschenden Gesellschaft, 29(3): 151-306.

Farjon, A. (2005): Pines: Drawings and Descriptions of the Genus Pinus ( $2^{\text {nd }}$ ed. $) .-$ Brill Academic Publishers, Leiden, $236 \mathrm{pp}$.

Florin, R. (1963): The distribution of conifer and taxad genera in time and space. - Acta Horti Bergiani, 20(4): 121-312.

Geyler, Th., Kinkelin, F. (1887): Oberpliocän-Flora aus den Baugruben des Klärbeckens bei Niederrad und der Schleuse bei Höchst a. M. - Abhandlungen der Senckenbergischen Naturforschenden Gesellschaft, 15: 1-47.
Gossmann, R. (1983): Die Niederrheinische Bucht im Tertiär. - Der Aufschluß, 34: 457-477.

Gossmann, R., Gregor, H.-J., Lieven, U. (2006): Die Niederrheinische Bucht und ihre Tertiärablagerungen (Braunkohlen, Kiese, Sande, Tone). - Documenta naturae, Sonderband no. 43: 1-26.

Gregor, H.-J. (1994): Neue Pflanzenfossilien aus dem niederrheinischen Tertiär IX. - Die niederrheinische Braunkohle - ein literarischer Überblick und neue paläobotanische Befunde aus diversen Tagebauen. - Documenta naturae, 89: 20-30.

Hager, H. (1977): Zur geologischen Gliederung der Schichtenfolge im rheinischen Braunkohlenrevier. - Braunkohle, Wärme und Energie, 29: 116-112.

Kilpper, K. (1968): Koniferen aus den tertiären Deckschichten des niederrheinischen Hauptflözes. - Palaeontographica, B, 121(4-6): 159-168.

Kinkelin, F. (1900): Beiträge zur Geologie der Umgegend von Frankfurt a. M. - Berichte der Senckenbergischen Naturforschenden Gesellschaft, 1900: 121-162.

Klaus, W. (1980): Neue Beobachtungen zur Morphologie des Zapfens von Pinus und ihre Bedeutung für die Systematik, Fossilbestimmung, Arealgestaltung und Evolution der Gattung. - Jahrbuch für Systematik und Evolution, 1980: 137-171.

Klaus, W. (1989): Mediterranean pines and their history. Plants Systematics and Evolution, 162: 133-163. https://doi.org/10.1007/BF00936915

Krüssmann, G. (1983): Handbuch der Nadelgehölze (2 $2^{\text {nd }}$ ed.). - Verlag Paul Parey, Berlin, Hamburg, 396 pp.

Kvaček, Z. (1976): Towards nomenclatoral stability of European Tertiary conifers. - Neues Jahrbuch für Geologie und Paläontologie, Monatshefte, 1976(5): 284-300.

Kvaček, Z., Lieven, U., Gregor, H.-J. (2014a): Pinus timle$r i$ - ein wichtiges Element aus der pliozänen Flora des Tagebaues Hambach (RWE Power AG). - Documenta naturae, 195(1): 21-45.

Kvaček, Z., Teodoridis, V., Mazouch, P., Roiron, P. (2014b): Seed cones of Pinus L. (sect. Pinus, subsect. Pinaster Loudon, Sula group) from the late Neogene and early Pleistocene of Europe. - Palaeontographica, B, 291(16): 131-163.

Mädler, K. (1939): Die pliozäne Flora von Frankfurt a. M. Abhandlungen der Senckenbergischen Naturforschenden Gesellschaft, 442: 1-202.

Mai, D. H. (1986): Über Typen und Originale tertiärer Arten von Pinus L. (Pinaceae) in mitteleuropäischen Sammlungen - Ein Beitrag zur Geschichte der Gattung in Europa. - Feddes Repertorium, 97(9-10): 571-605.

Mai, D. H. (1994): Fossile Koniferenreste in der meridionalen Zone Europas. - Feddes Repertorium, 105(3-4): 207-227. https://doi.org/10.1002/fedr.19941050315

Mai, D. H. (1995): Tertiäre Vegetationsgeschichte Europas Methoden und Ergebnisse. - G. Fischer Verlag, Jena, $691 \mathrm{pp}$.

Page, C. N. (1974): Morphology and affinities of Pinus canariensis. - Notes, Royal Botanical Garden Edinburgh, 33(2): 317-323.

Pingen, M. (2001): Eine Karpoflora aus dem Untermiozän des Tagebaus Fortuna-Garsdorf (Nordrheinwestfalen, Deutschland). - Palaeontographica, B, 259(1-6): 221-233. 
Schneider, H., Thiele, S. (1965): Geohydrologie des Erftgebietes. - Ministerium für Ernährung, Landwirtschaft und Forste des Landes Nordrhein-Westfalen, Düsseldorf, $185 \mathrm{pp}$.

Schütt, P., Weisgerber, H., Schuck, H. J., Lang, U. M., Stimm, B., Roloff, A. (eds) (2004): Lexikon der Nadelbäume. Verbreitung, Beschreibung, Ökologie, Nutzung, Sonderausgabe. - Nikel-Verlag, Hamburg, 619 pp.

Seward, A. C. (1919): Fossil plants IV. - University Press, Cambridge, 543 pp.

Van der Burgh, J. (1983): Allochthonous seed and fruit floras from the Pliocene of the Lower Rhine Basin. - Review of Palaeobotany and Palynology, 40: 33-90. https://doi.org/10.1016/0034-6667(83)90004-0

Wutzler, B. (1989): Pflanzenfossilien - Spuren tertiärer Wälder im Dürener Land. - Eifeljahrbuch 1989: 161-171.

\section{Explanations of plates}

\section{PLATE 1}

Pinus timleri Kinkelin in Engelhardt et Kinkelin, Neogene, upper Lower Pliocene (Zanclean), the Kieseloolith Formation, the Bergheim Member (Rotton sand, Horizon 9B) from Hambach open cast mine, Germany

1. Cone 1 from M. Pingen collection (Hürtgenwald-Gey).

a: Rounded side with conically raised umbos.

b: Same specimen from different lateral view. Rounded side (with conically raised um bos) on right side and and on left side flat umbos of the apophyes (visible on the top left side).

c: Smooth side detail. Apophyses are slightly raised.

d: Rounded side detail. Note subhemispherical apophyses, partially with raised navel on umbo.

e: Apical view. Roundish and compact cone apex. The apophyses with significant umbos on the rounded side are visible on the right, the reduced apophyses on the smooth side can be seen on the bottom and top.

f: Short peduncle on base of cone (rounded side) with hemisphaerical umbos.

2. Cone from Spaeth collection (Euskirchen-Kleinbüllesheim, Germany).

a: Break surface detail on the cone base. Smooth right side, rounded side in all other directions.

b: Apophyses of rounded right side and of smooth left side.

c: Opposite view (apophyses of smooth right side, rounded left side). Break surface of cone visible.

d: Rounded side: note thick, edged umbos and raised navels with partially hook-shaped ends.

\section{PLATE 2}

Pinus timleri KinKelin in Engelhardt et Kinkelin, Neogene, upper Lower Pliocene (Zanclean), the Kieseloolith Formation, the Bergheim member (Rotton sands, Horizon 9b) from Hambach open cast mine, Germany

1. Partially opened seed cone from Augsburg Natural History Museum (Reg.-Nr. 2016-67/1979, leg. Gregor).

a: Smooth side with flat apophyses bearing small mucros. Bottom left and right large hook-shaped elongated apophyses of the rounded side.

b: Opposite view. Rounded side with thick slightly recurved umbos.

c: Rounded side with umbo details.

2. Apical seed cone fragment from Goldfuß Museum at Steinmann Institute, University of Bonn (STIPB-PB 21243, leg. Gossmann).

a: Strongly recurved umbos of the rounded side.

b: Lightly recurved apophyses of the smooth side.

c: Apical view. Right, top and bottom of picture show large umbos of rounded side. Left part shows apophyses of the other side.

Pinus timleri Kinkelin in Engelhardt et Kinkelin, Neogene, Pliocene (Zanclean), Lower Kieseloolith Formation, Upper Erft member (Hauptkies-Schichten, Horizon 8B) from Frechen open cast mine, Germany (Ruhr Museum Essen - RE 551.782.210 A 0066/1, leg. Kilpper)

3. Apical fragment of seed cone, note depressed erosion scars of flat apophyses (top right). (Adapted from Mai 1986: pl. XLV, fig. 1.) 
PLATE 1
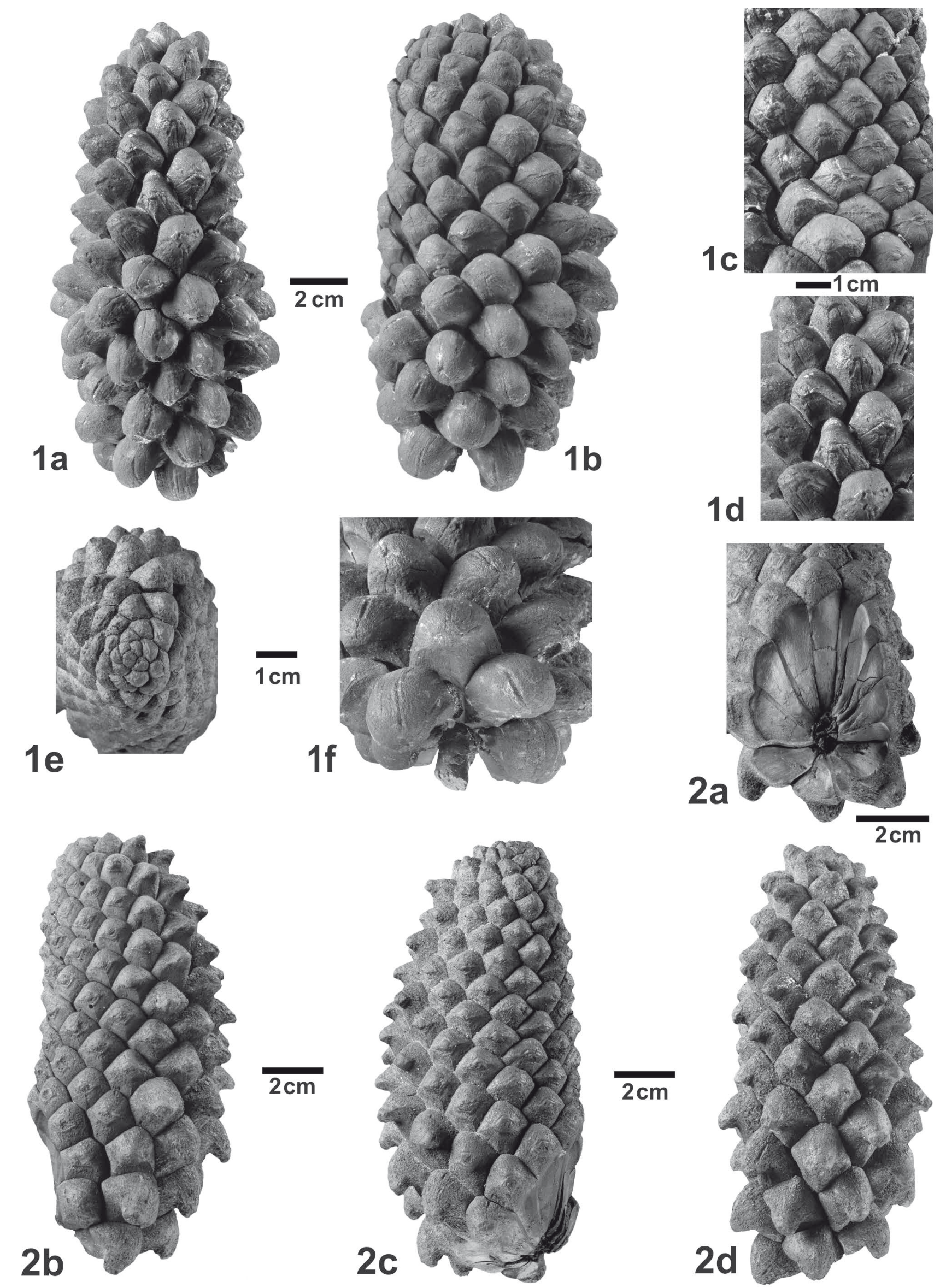
PLATE 2
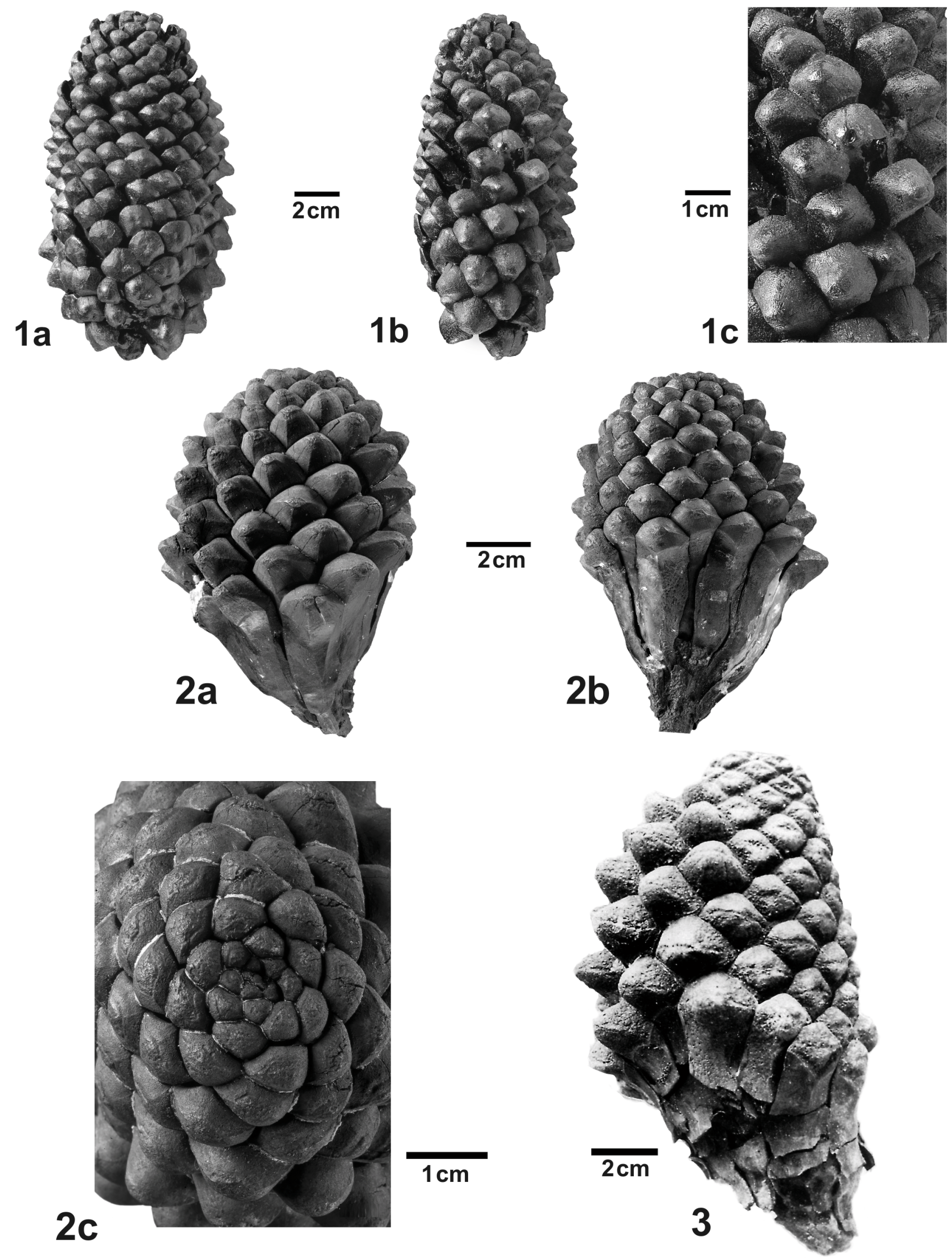